\title{
An Experimental Investigation of the Factors Which Affect on the Performance of a Single Basin Typical Double Slope Solar Still for Water Desalination
}

\author{
A. S. Zedan'1, 2, S. A. M. Nasr Eldin'1,3 \\ ${ }^{1}$ Mechanical Engineering Department, Collage of Engineering, King Khalid University, Abha, Saudi Arabia \\ ${ }^{2}$ Mechanical Engineering Department, Collage of Engineering at Shoubra, Benha University, Cairo, Egypt \\ ${ }^{3}$ Mechanical Engineering Department, Collage of Engineering, Benha University, Benha, Egypt \\ Email: aszedan@yahoo.com, kku_researchcenter@yahoo.com
}

Received 20 May 2015; accepted 15 June 2015; published 18 June 2015

Copyright (C) 2015 by authors and Scientific Research Publishing Inc.

This work is licensed under the Creative Commons Attribution International License (CC BY).

http://creativecommons.org/licenses/by/4.0/

CC) (i) Open Access

\begin{abstract}
Solar energy is very useful in the process of desalination especially for areas that suffer from a lack of clean water resources. In recent years, many people have been using solar still. Therefore the raising of the productivity and efficiency of solar still represents the most important problems that need further research. The present work aims to study the effect of preheating the water entering to still and the effect of reducing pressure inside the still on the productivity of the solar still. Therefore in present work two identical single basin typical double slope solar stills of the inner basin dimensions for each still $2 \mathrm{~m} \times 1 \mathrm{~m} \times 0.08 \mathrm{~m}$, have been designed and fabricated with mild steel plate. One of them is conventional solar still and the other is modified with flat plate collector and vacuum pump to study the effect of preheating and vacuum on the performance of solar still. The experimental measurements are made to enhance the solar still productivity by firstly preheating the water entering the still using flat plate collector and secondly by integrating the still basin with vacuum pump. The results show that preheating the water entering the still increases the water productivity by amount about $27.7 \%-29.3 \%$. The results also show that decreasing pressure inside the still using vacuum pump improves the solar still water productivety by amount about $21.8 \%-23.9 \%$.
\end{abstract}

\section{Keywords}

Desalination, Basin Solar Double Slope Still, Vacuum, Water Productivity

How to cite this paper: Zedan, A.S. and Nasr Eldin, S.A.M. (2015) An Experimental Investigation of the Factors Which Affect on the Performance of a Single Basin Typical Double Slope Solar Still for Water Desalination. Energy and Power Engineering, 7, 270-277. http://dx.doi.org/10.4236/epe.2015.76026 


\section{Introduction}

In recent years the needs for clean water were increased to face population increment, agriculture development, industrial development and generating electric power. Desalination using solar energy which converts the salt water into clean water is necessary to development of coastal and desert areas.

Enhancing the still's productivity has been studied by several investigators, Murugavel et al. [1] made a review to the progress in improving the effectiveness of simple single basin solar still

They showed that the basin time solar stills were simple in design, manufacturing, operation and economy. In solar desalination process, the productivity of the solar still is very low in the range of $2-5$ liters $/ \mathrm{m}^{2} / \mathrm{day}$ only compared to other conventional desalination systems. The problem is to enhance the amount of water produced. Akash et al. [2] presented experimental results obtained using the basin type solar still. The experiments were performed using a solar still with various cover tilt angles. An optimum tilt angle for water production was found to be 358 during the month of May. The results showed that water production decreased in a somewhat linear relationship with increasing water depth in the still. Collins et al. [3] made tests on a simple solar still coupled with an external condenser.

Singh et al. [4] devolved a double slope hybrid (PVT) active solar still which was designed, fabricated and experimentally tested under field conditions for different configurations. Parallel forced mode configuration of the solar still would produce higher yield than the other configurations and obtained as $7.54 \mathrm{~kg} / \mathrm{day}$ with energy efficiency of 17.4

Moses et al. [5] made attempts to increase the productivity of water by using different absorbing materials, depths of water, heat storage medium and also by providing low pressure inside the still basin. They greatly improved the rate of evaporation and hence the rate of condensation on the cooler surface

Barden et al. [6] performed the tests in solar still augmented with flat plate collector using tap water and saline water. They found that the mass of distilled water production using augmentation increased by $23.1 \%$ in case of tap water as a feed and by $52 \%$ in case of salt water as a feed. Badran and Al-Tahainesh [7] presented the effect of coupling a flat plate collector on the solar still productivity. The results showed that the output of the still was the maximum for the least water depth in the basin $(2 \mathrm{~cm})$. Also, the increase in water depth had decreased the productivity while the still productivity was found to be proportional to the solar radiation intensity

Yadav [8] studied the performance of a solar still coupled with a flat plate collector using thermosyphon mode and forced circulation mode for New Delhi climatic condition. The author found that the system using the forced circulation mode gave 5\% - 10\% higher yield than that of the thermosyphon mode and 30\% - 35\% enhancement in the yield was observed with simple solar still.

Badran et al. [9] made experimental study which presented a thermal design of a passive solar water distillation system with vacuum. The designed model consists of a glass cover, basin water equipped with reflecting mirror and insulation, and controlled vacuum pump to create vacuum inside the still to decrease the saturation temperature of water and in order to increase the yield. Feed water in the basin is heated by solar energy, and the evaporated water is condensed by inner glass cover. The temperatures at different locations in the system, the received amount of solar radiation, and the distilled water produced were determined. The highest temperature developed inside the distilling device was $51^{\circ} \mathrm{C}$ at ambient temperature of $24^{\circ} \mathrm{C}$, the daily water production was 1.2 liters $/ \mathrm{m}^{2} /$ day, and the efficiency of the solar still was $15 \%$. Kabeel [10] made an experimental investigation to enhancement of the modified solar still integrated with condenser using Nano fluids. The results showed that integrating the solar still with external condenser increased the distillate water yield by about 53.2\%. And using Nano fluids improved the solar still water productivity by about $116 \%$ when the still integrated with the external condenser.

\section{Experimental Setup}

Two Identical a single basin double slope solar still have been designed and fabricated with mild steel plate, as shown in Figure 1(a) and Figure 1(b). The overall size of the inner basin for each still is $2 \mathrm{~m} \times 1 \mathrm{~m} \times 0.08 \mathrm{~m}$, and that of the outer wooden basin is $2.2 \mathrm{~m} \times 1.2 \mathrm{~m} \times 0.20 \mathrm{~m}$. The gap between the inner and outer basin is packed with sawdust as insulation material. The top of the solar still is covered with glasses of thickness 4 mm, inclined at $20^{\circ}$ on both sides. The condensed water is collected in the rectangle shaped drainage provided below the glass lower edge of the still. The condensate collected is continuously drained through flexible hose and stored in a jar on both side of the still. The modified still is equipped with the flat plate collector of area $2 \mathrm{~m} \times 1 \mathrm{~m}$ 


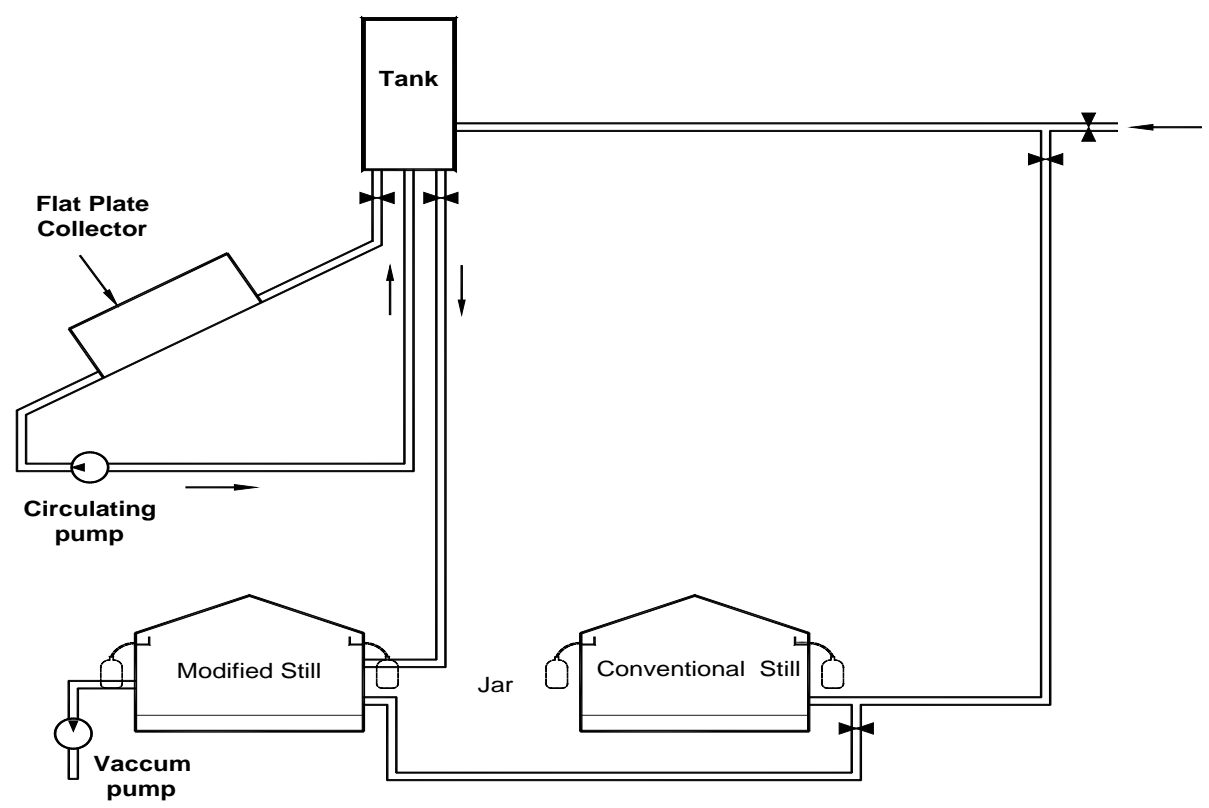

(a)

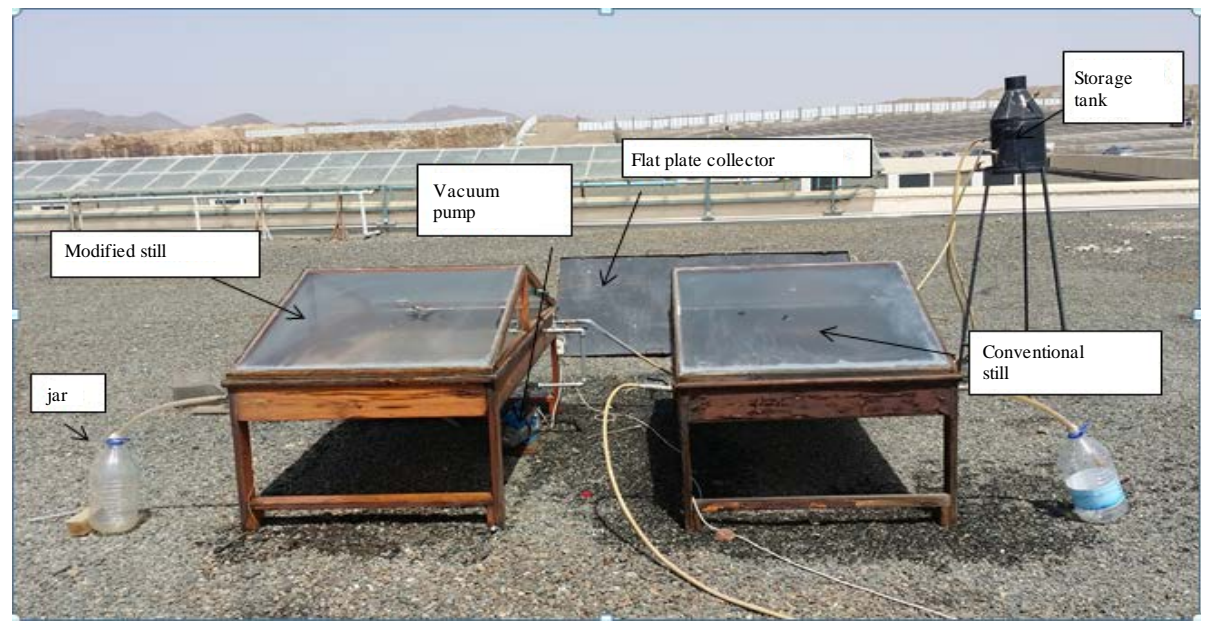

(b)

Figure 1. (a) Schematic Diagram of Experimental Setup. (b) Photograph of Experimental Setup.

which is designed and fabricated. The modified still is also equipped with the selected vacuum pump.

The experimental setup is suitably instrumented to measure the temperatures at different points of the still (basin water temperature, glass cover temperatures and ambient temperature), total solar radiation and the amount of distillate water. The temperatures are measured by thermocouples. Thermocouples were fixed at various points to measure basin water temperature, evaporative basin chamber temperature, inside and outside glass cover temperature, flat plate collector inlet \& outlet temperature. A hole in the basin side wall allows inserting the thermocouples for the measurement of the basin water temperature. The hole is closed with insulating material to avoid the heat and vapor loss. One thermocouple is exposed to atmosphere to measure ambient temperature. The systems were operated with and without coupling flat plate collector at Abha City location which lies on the altitudes of $2200 \mathrm{~m}$ above sea level for a water depth of $5 \mathrm{~mm}$. Also the systems were operated with and without vacuum pump. The solar radiation intensity is measured by a solar meter.

\section{Experimental Procedures}

Experiments are performed at Faculty of Engineering KKU University, Abha City which lies on the altitudes of 
$2200 \mathrm{~m}$ above sea level, Saudi Arabia. The experiments were carried out at the period from 9 a.m. to 16 p.m. during Jun 2014 to December 2014. The solar radiation, atmospheric temperature, basin water temperature, glass temperature and distilled water productivity were measured every hour. However, the accumulated productivity during the period of measurements had also been measured in each test. The depth of the water in the solar stills is holding constant during the test manually by using a make-up water tank and control valve every hour. All measurements were performed to evaluate the performance of a single basin typical double slope solar still for water desalination and the modified of a single basin typical double slope solar still for water desalination with preheating using flat plate collector and with vacuum pump under the outdoors of Abha City conditions.

The groups of experiments are performed as follows:

a) The first group of tests was done with water depth of $5 \mathrm{~mm}$ in each of basin stills from 9 a.m. to 16 p.m. to compare the performance of two stills without any modifications

b) The second group of tests was done at constant water depth of $5 \mathrm{~mm}$ in each of basin stills. The performance of the modified basin still is investigated with preheating the water entering the still. At the same time the performance of the typical conventional still is investigated.

c) The third group of tests was done at constant water depth of $5 \mathrm{~mm}$; the performance of the modified basin still is investigated with vacuum pump was compared with the conventional one,

\section{Results and Discussions}

A number of experimental tests were done to demonstrate the objective of the Present work. All experimental tests are performed at Faculty of Engineering KKU University, Abha City which lies on the altitudes of $2200 \mathrm{~m}$ above sea level, Saudi Arabia. Figure 2 shows the variation of solar radiation, atmospheric temperature, basin water temperature, and glass temperature for both still under the same conditions without operating any modification. Figure 2 shows that the two stills ( conventional and modified ) have nearly the same performance when they working under the same condition without operating any modifications The solar radiation increases in the morning hours reaching its maximum values around midday and then decreases in the afternoon. Also, it can be observed from Figure 2 that, the maximum temperature is obtained during the period from 11 a.m. to 2 p.m. Also, it is observed that the temperatures at all points increase in the morning hours to reach maximum value around midday before it start to reduce late in the afternoon. The same trend is observed for the profile of the solar radiation incident during the days of the measurements

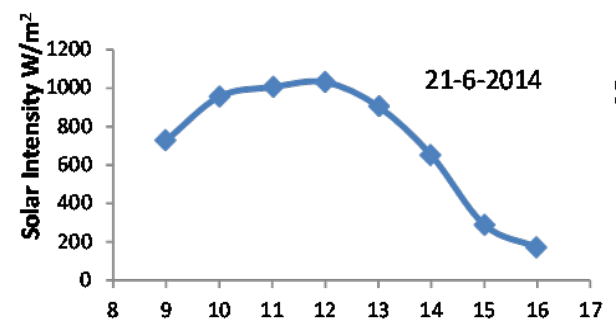

(a)

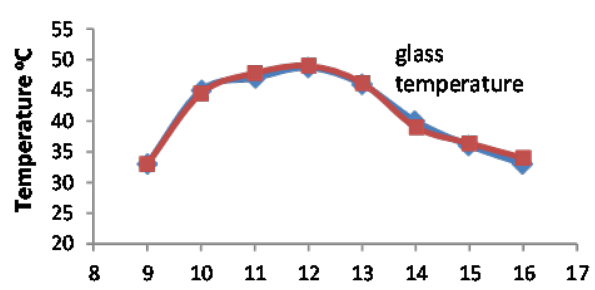

(c)

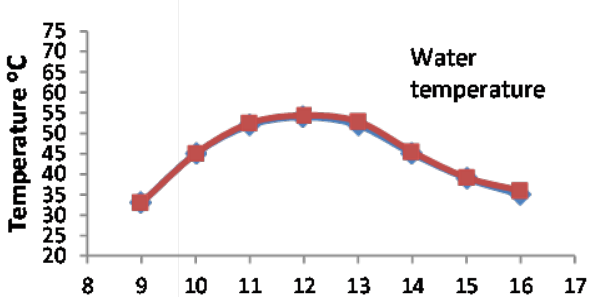

(b)

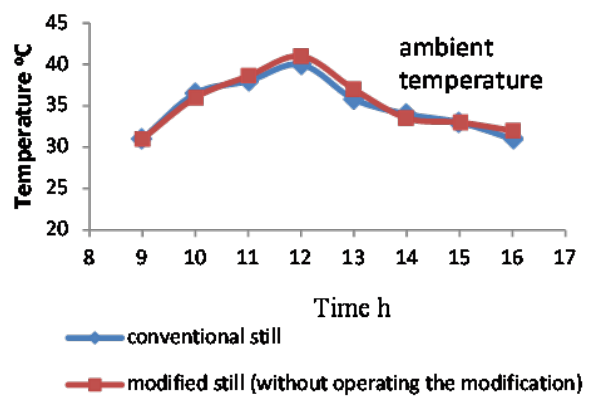

(d)

Figure 2. The hour solar radiation variation and temperature variation for conventional and modified still. 


\subsection{Effect of Preheating the Water Entering the Still}

Figure 3 shows comparisons between the hourly variations of ambient temperature, water temperature and glass temperature for the conventional and the modified solar stills at day of 24-10-2014. The hourly freshwater productivity and accumulated productivity are illustrated in Figure 4, Figure 5 and Figure 6. The amount of accumulated distillate water for the modified solar still is greater than that of conventional still due to preheating the water entering the modified still which cause the evaporation inside modified solar still starts before that inside conventional one. Also the preheating increases the evaporation rate inside the modified solar still. The preheating water entering the solar still increases the productivity by amount about $27.7 \%-29.3 \%$ during the measuring period from morning at 9 a.m. to 16 p.m. as shown in Table 1.

\subsection{Effect of Vacuum on the Productivity of Solar Still}

In the present work, the vacuum pump incorporated to modify solar still reduces the pressure inside the still and boiling water temperature will be reduced. The measurements using vacuum pump are taken at two days (23-12-2014 and 30-12-2014) as illustrated in Table 2. At vapor pressure of water of $39 \mathrm{kPa}$ the boiling water temperature is nearly $75^{\circ} \mathrm{C}$ and at vapor pressure of water of $25 \mathrm{kPa}$ the boiling water temperature is nearly $65^{\circ} \mathrm{C}$.

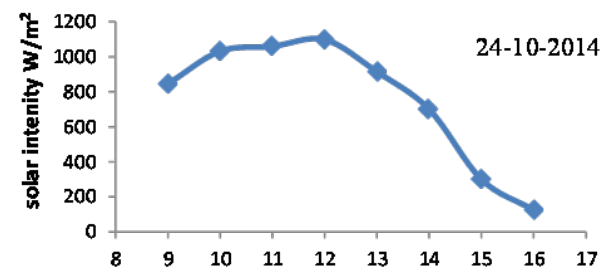

(a)

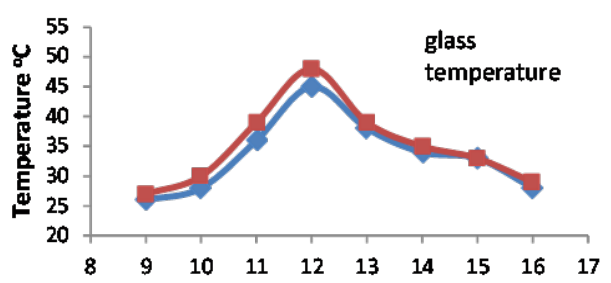

(c)

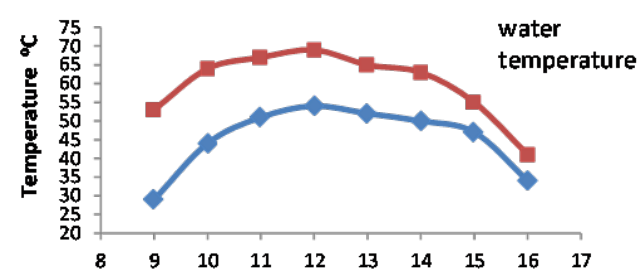

(b)

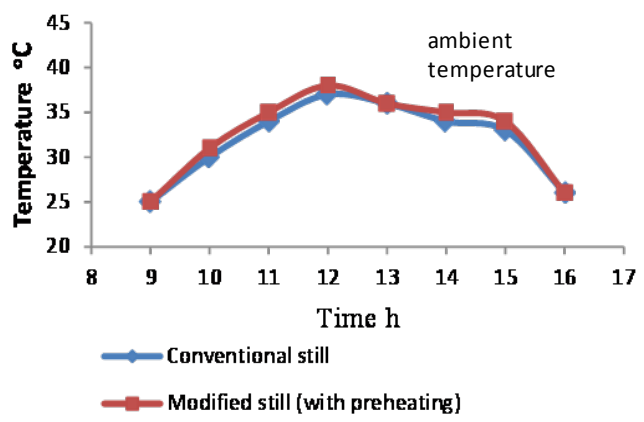

(d)

Figure 3. The hour solar radiation variation and temperatur variation for conventional and modified still ( with preheating).

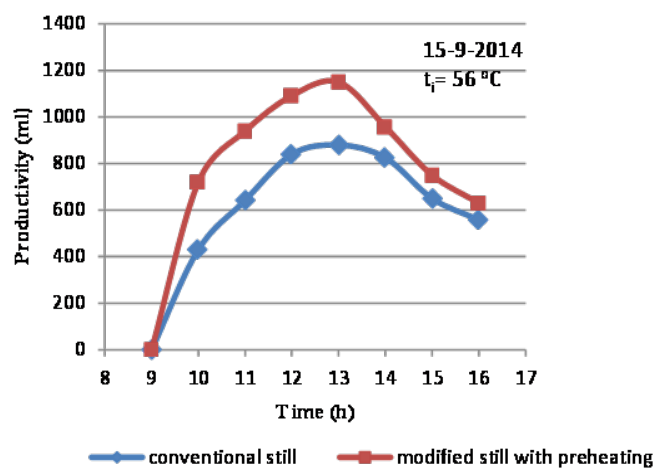

(a)

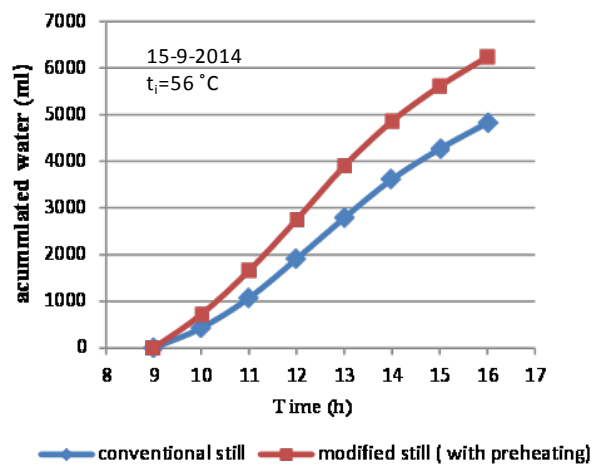

(b)

Figure 4. (a) Productivity vs Time for convetional and modified still (with preheating). (b) Acummlation of produced water for convetional and modified still (with preheating). 


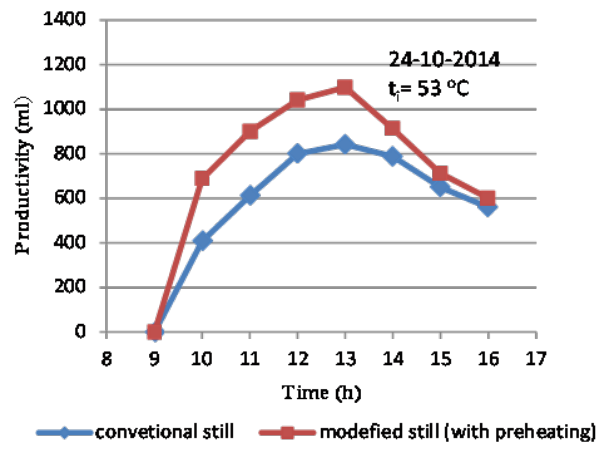

(a)

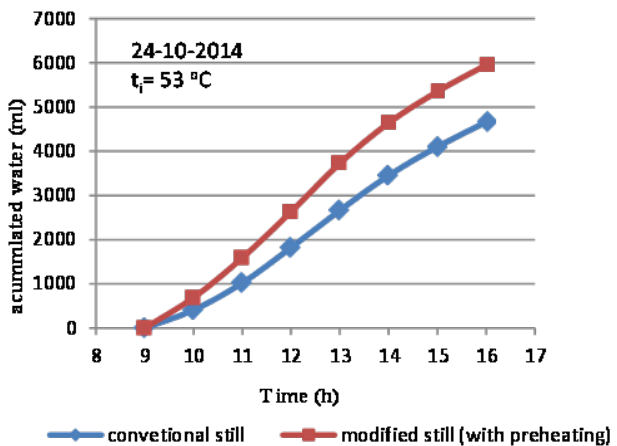

(b)

Figure 5. (a) Productivity vs Time for convetional and modified still (with preheating). (b) Acummlation of produced water for convetional and modified still (with preheating).

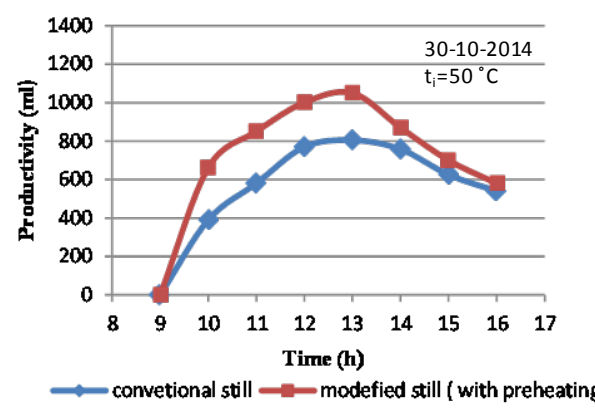

(a)

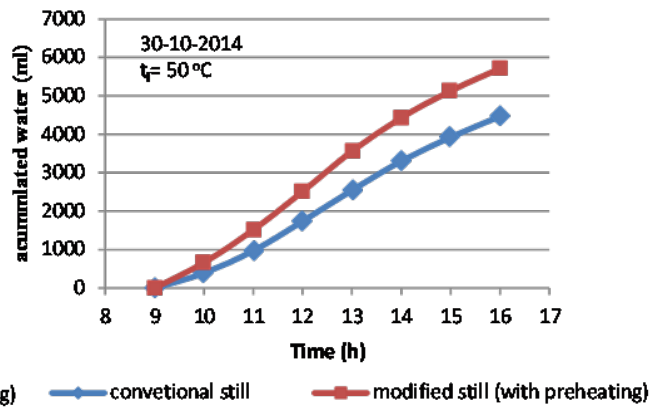

(b)

Figure 6. (a) Productivity vs Time for convetional and modified still (with preheating). (b) Acummlation of produced water for convetional and modified still (with preheating).

Table 1. Accumulated water for some days of measuring for conventional and the modified still with preheating.

\begin{tabular}{ccccccc}
\hline & & \multicolumn{2}{c}{ Inlet temperature $\mathrm{t}_{\mathrm{i}}$} & \multicolumn{2}{c}{ Productivity (D) } & $\begin{array}{c}\text { Productivity } \\
\text { increase } \%\end{array}$ \\
\cline { 3 - 6 } Date of Measuring day & Period & $\begin{array}{c}\text { Conventional } \\
\text { still }\end{array}$ & $\begin{array}{c}\text { Modified } \\
\text { Still with preheating }\end{array}$ & $\begin{array}{c}\text { Dconvetional } \\
(\mathrm{ml})\end{array}$ & $\begin{array}{c}\text { Dmodified } \\
\text { (ml) }\end{array}$ & \\
\hline $15-9-2014$ & 9 a.m.:16 p.m. & $31^{\circ} \mathrm{C}$ & $56^{\circ} \mathrm{C}$ & 4825 & 6240 & 29.3 \\
$24-10-2014$ & 9 a.m.:16 p.m. & $29^{\circ} \mathrm{C}$ & $53^{\circ} \mathrm{C}$ & 4660 & 5951 & 27.7 \\
$30-10-2014$ & 9 a.m.:16 p.m. & $28^{\circ} \mathrm{C}$ & $50^{\circ} \mathrm{C}$ & 4468 & 5713 & 27.9 \\
\hline
\end{tabular}

Table 2. Accumulated water for some days of measuring for conventional and the modified still with vacuum pump.

\begin{tabular}{|c|c|c|c|c|c|c|}
\hline \multirow{2}{*}{$\begin{array}{c}\text { Date of } \\
\text { Measuring day }\end{array}$} & \multirow{2}{*}{ Period } & \multicolumn{2}{|c|}{ pressure } & \multicolumn{2}{|c|}{ Productivity (D) } & \multirow{2}{*}{$\begin{array}{c}\text { Productivity } \\
\text { increase \% }\end{array}$} \\
\hline & & $\begin{array}{c}\text { Conventional still } \\
\text { without vacuum pump }\end{array}$ & $\begin{array}{c}\text { Modified } \\
\text { Still with vacuum pump }\end{array}$ & $\begin{array}{l}\mathrm{D}_{\text {convetional }} \\
\quad(\mathrm{ml})\end{array}$ & $\begin{array}{l}\mathrm{D}_{\text {modified }} \\
(\mathrm{ml})\end{array}$ & \\
\hline 23-12-2014 & 9 a.m.:16 p.m. & & $39 \mathrm{kPa}\left(75^{\circ} \mathrm{C}\right)$ & 3878 & 4722 & 21.8 \\
\hline $30-12-2014$ & 9 a.m.:16 p.m. & & $25 \mathrm{kPa}\left(65^{\circ} \mathrm{C}\right)$ & 4276 & 5298 & 23.9 \\
\hline
\end{tabular}

The vacuum pump will be operated intermittently to maintain the vacuum constantly and at that time a separate condensation chamber is used to condense the vapor leaving through the vacuum pump.

Figure 7 and Figure 8 show the productivity for conventional and modified solar still with vacuum for the 


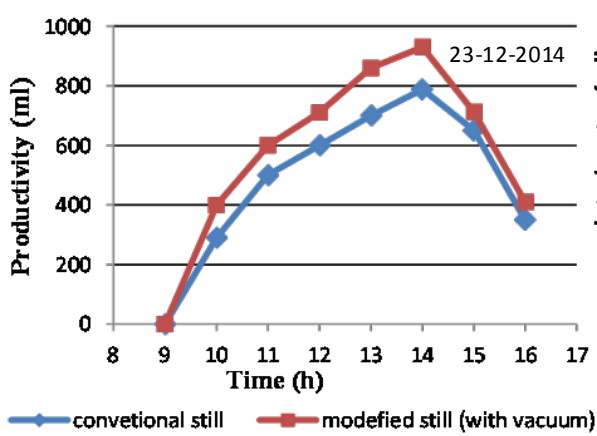

(a)

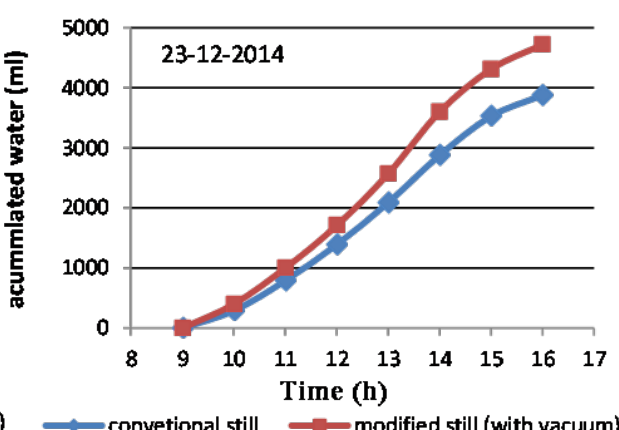

(b)

Figure 7. (a) Productivity vs time for convetional and modified still (with vacuum). (b) Acummlation of produced water for convetional and modified still (with vacuum).

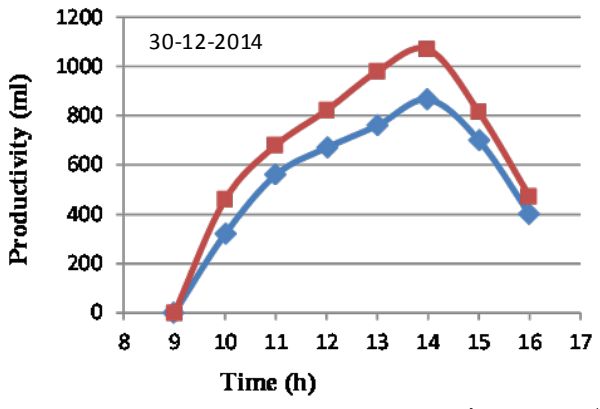

$\longrightarrow$ conventional still

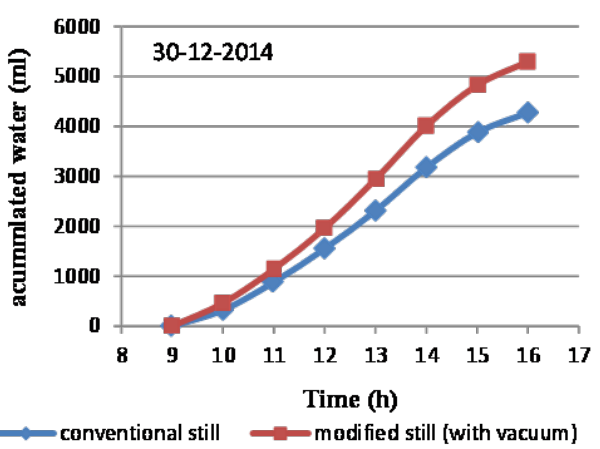

(b)

Figure 8. (a) Productivity vs Time for convetional and modified still (with vacuum). (b) Acummlation of produced water for convetional and modified still (with vacuum).

Table 3. Average solar radiation intensity and accumulated water for some days of measuring for the conventional still.

\begin{tabular}{ccc}
\hline Measuring day & $\begin{array}{c}\text { Average solar radiation intensity during } \\
\text { operational period }(9 \text { a.m. }-16 \text { p.m. })\end{array}$ & $\begin{array}{c}\text { Accumulated water } \\
(\mathrm{ml})\end{array}$ \\
\hline $21-6-2014$ & $6.272 \mathrm{kWh} / \mathrm{m}^{2} /$ day $\left(22.5792 \mathrm{MJ} / \mathrm{m}^{2} /\right.$ day $)$ & 4825 \\
$15-9-2014$ & $6.047 \mathrm{kWh} / \mathrm{m}^{2} /$ day $\left(21.7692 \mathrm{MJ} / \mathrm{m}^{2} /\right.$ day $)$ & 4660 \\
$24-10-2014$ & $5.897 \mathrm{kWh} / \mathrm{m}^{2} /$ day $\left(21.2292 \mathrm{MJ} / \mathrm{m}^{2} /\right.$ day $)$ & 4468 \\
$30-10-2014$ & $5.733 \mathrm{kWh} / \mathrm{m}^{2} /$ day $\left(20.6388 \mathrm{MJ} / \mathrm{m}^{2} /\right.$ day $)$ & 4410 \\
$30-12-2014$ & $5.630 \mathrm{kWh} / \mathrm{m}^{2} /$ day $\left(20.268 \mathrm{MJ} / \mathrm{m}^{2} /\right.$ day $)$ & 4276 \\
$23-12-2014$ & $5.339 \mathrm{kWh} / \mathrm{m}^{2} /$ day $\left(19.2204 \mathrm{MJ} / \mathrm{m}^{2} /\right.$ day $)$ & 3878 \\
\hline
\end{tabular}

water level of $5 \mathrm{~mm}$ at different two days. The figures show an increase in the water productivity of the vacuum solar still due to low pressure compared with the still working at ambient conditions. This is mainly due to the existence low pressure caused higher evaporation rate inside the still. The results show that using vacuum pump improves the solar still water productivity by about $21.8 \%$ to $23.9 \%$

\subsection{Effect of the Average Solar Radiation Intensity}

Table 3 shows the results of the average solar radiation intensity at a different days of measurement at the period 9 a.m. -16 p.m. The relation between the average solar radiation intensity during the period 9 a.m. -16 p.m. and the total amount of produced water during the same period at different days of measurement is shown in Figure 9. The figure shows that the amount of produced distilled water is directly proportional to the average 


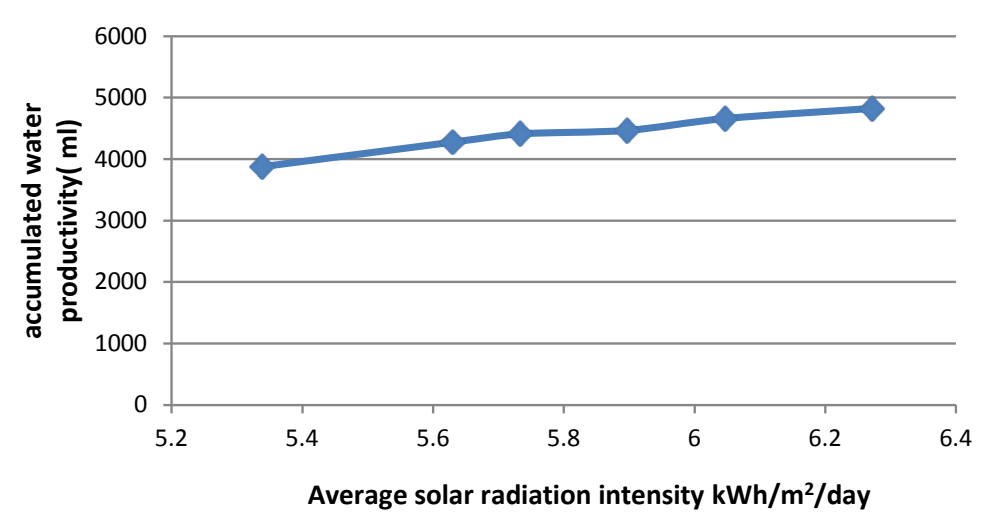

Figure 9. Average solar radiation intensity versus accumulated water productivity.

solar radiation intensity.

\section{Conclusion}

In the present work, the effects of preheating water entering the still and decreasing pressure in solar still are experimentally studied at Faculty of Engineering, KKU University, Abha City, which lies on the altitudes of $2200 \mathrm{~m}$ above sea level, Arabia. The geographical location may be have considerable effect on the increased water productivity, especially for those sites which lie on the altitudes above sea level, where low boiling point of water and also saturation pressure are lower than the level of standard atmospheric pressure. It is found that the water productivity of basin solar still increases with the average solar radiation intensity increased. Preheating the water entering the still increases the water productivity by amount about $27.7 \%-29.3 \%$. Decreasing pressure inside the still using vacuum pump improves the solar still water productivity by amount about $21.8 \%-23.9 \%$

\section{References}

[1] Murugavel, K., Chockelingam, K.K.S. and Srither, K. (2008) Progresses in Improve the Effectiveness of the Single Basin Passive Solar Still. Desalination, 220, 677-686. http://dx.doi.org/10.1016/j.desal.2007.01.062

[2] Akash, B.A., Mohsen, M.S. and Nayfeh, W. (2000) Experimental Study of the Basin Type Solar Still under Local Climate Conditions. Energy Conversion \& Management, 41,883-890.

[3] Collins, R.A. and Thomson, T. (1961) Forced Convection Multiple Effect Still for Desalting and Brackish Water. Proceedings of the United Nations Conference on New Sources, Rome, 21-31 August 1961, 205-217.

[4] Singh, G., Kumar, S. and Tiwari, G.N. (2011) Design, Fabrication and Performance Evaluation of a Hybrid Photovoltaic Thermal (PVT) Double Slope Active Solar Still. Desalination, 277, 399-406.

[5] Gnanadason1, K.S., Kumar, P.S., Sivaraman, G. and Daniel, J.E.S. (2011) Design and Performance Analysis of a Modified Vacuum Single Basin Solar Still. Smart Grid and Renewable Energy, 2, 388-395. http://dx.doi.org/10.4236/sgre.2011.24044

[6] Badran, A.A., Al-Hallaq, A.A., Eyal Salman, I.A. and Odat, M.Z. (2005) A Solar Still Augmented with a Flat Plate Collector. Desalination, 172, 227-234.

[7] Badran, O.O. and Al-Tahaineh, H.A. (2005) The Effect of Coupling a Flat plate Collector on the Solar Still Productivity. Desalination, 183, 137-142.

[8] Yadav, Y.P. (1991) Analytical Performance of a Solar Still Integrated with a Flat Plate Solar Collector: Thermosiphon Mode. Energy Conversion and Management, 31, 255-263.

[9] Badran, O., Beithou, N., Al Alawin, A., Awad, A., Abdelhadi, Y. and Al-Mofleh, A. (2013) Experimental Study of a Vacuumed Solar Still System. International Journal of Applied Power Engineering, 2, 99-104. http://dx.doi.org/10.11591/ijape.v2i3.1857

[10] Kabeel, A.E., Omara, Z.M. and Essa, F.A. (2013) Enhancement of Modified Solar Still Integrated with External Condenser Using Nanofluids: An Experimental Approach. 17th International Water Technology Conference, IWTC17, Istanbul, 5-7 November 2013, 1-9. 